\title{
STUDI EKSEGETIS 1KORINTUS 10: 1-5 DAN KONTRIBUSINYA DALAM MEMAHAMI PRINSIP BAPTISAN ANAK
}

\author{
Suleni \\ Sekolah Tinggi Teologia Reformed Bengkayang - Kalimantan Barat \\ suleniserve@gmail.com
}

\begin{abstract}
Infant Baptism is a sacrament in the Chruch. But at this time many rejected the practice of infant baptism. The rejection comes from several Christian group. Many arguments have been given to assert the validity of Biblical infant baptism. However, these arguments have not yet been accepted by opponents of infant baptism. Through this article the author tries to contribute by 1Corinthians 10:1-5 as a basis for understanding infant baptism. This verse has not been widely exposed by Theologians to defend the argument about the validity of infant baptism. Thus, the reader can understand the true principle of infant baptism.
\end{abstract}

Key Words: Validity, Child baptism, Exegetical Study 1Corinthians 10: 1-5

Abstraksi: $\quad$ Baptisan anak merupakan salah satu sakramen dalam gereja. Namun, pada masa kini masih banyak yang menolak pelaksanaan baptisan anak. Penolakan tersebut hadir dari beberapa kelompok Kristen. Banyak argumen telah diberikan untuk menyatakan keabsahan baptisan anak secara Alkitabiah. Tetapi, argumen-argumen tersebut masih belum diterima oleh para penentang baptisan anak. Melalui artikel ini penulis mencoba memberikan kontribusi melalui surat 1Korintus 10: 1-5 sebagai dasar untuk memahami baptisan anak. Ayat ini belum banyak di ekspos oleh para Teolog untuk mempertahankan argumen mengenai keabsahan baptisan anak. Dengan demikian, pembaca dapat memahami prinsip baptisan anak yang sesungguhnya.

Kata Kunci: Keabsahan, Baptisan anak, Studi Eksegetis 1Korintus 10: 1-5

\section{PENDAHULUAN}

Dalam artikel ini penulis memaparkan makna baptisan dan pemahaman mengenai prinsip baptisan anak. Prinsip baptisan anak ini dapat menjadi kontribusi bagi pemahaman orang percaya tentang makna baptisan yang sebenarnya. Sebab, baptisan anak tidak diterima sepenuhnya oleh beberapa golongan denominasi gereja. Terutama golongan Anabaptis yang menolak pelaksanaan baptisan anak. Sedangkan, baptisan anak merupakan bagian dalam baptisan kudus yang menggantikan sunat dalam Perjanjian Lama (PL). 
Sehingga, topik tentang problematika terhadap pemahaman baptisan anak akan dipertegas kembali dengan memberi kontribusi melalui 1Korintus 10: 1-5 yang belum pernah diekspos untuk digunakan dalam memahami prinsip baptisan anak. Pemaparan secara sistematis mengenai pengertian baptisan, makna baptisan, studi eksegetis baptisan anak dalam surat 1Korintus 10: 1-5, pemahaman terhadap prinsip baptisan anak dan kontribusi dalam memahami prinsip baptisan anak bagi orang percaya akan di jelaskan berhubung adanya perdebatan dan perbedaan pendapat para teolog. Golongan anabaptis berpendapat bahwa:

Anabaptists believe that baptism valid only when candidates confeses their faith in Christ and want to be baptized. This believer's baptism is opposed to baptism of infants, who are not able to make a conscious decision to be baptized. Anabaptist are those who are in a traditional line with the early anabaptists of the 16th century. Other Christian group with different roots also practice deliever's baptism, such as baptist, but these group are not seens as Anabaptist. The Amish, Hutterites and Mennonites are direct descendants of the early Anabaptist movement. Schwarzenau, Brethren, Bruderhof and the Apostolic Christian Church are considered later development among the anabaptists. ${ }^{1}$

Hal tersebut dapat dilihat dengan adanya golongan yang tidak melaksanakan baptisan anak karena meragukan keabsahannya. Perdebatan ini berhubungan dengan orang dewasa yang telah berhak menerima sakramen baptisan kudus sebab, sudah bisa mempertanggung jawabkan imannya dan memahami makna baptisan kudus. Dengan begitu baptisan merupakan satu topik yang terus dibicarakan oleh orang-orang percaya dan para Teolog di dunia. Baptisan tergolong satu topik yang menimbulkan perdebatan perbedaan pendapat. $^{2}$

1 N N, "Anabaptism," en.wikipedia.org, Wikipedia, diakses 25 September 2019, https: /len.wikipedia.org/wiki/Anabaptism.

2 Esra Alfred Soru, "Baptisan Anak Tanggung Jawab Orang Tua dan Gereja," anchoroflife.blogspot.com, Church of Life (blog), Juli 2011, https: //anchoroflife.blogspot.com/2011/07/baptisan-anak-tanggung-jawab-orang-tua.html. 


\section{METODE}

Untuk dapat memahami "Studi Eksegetis 1Korintus 10: 1-5 dan Kontribusinya Dalam Memahami Prinsip Baptisan Anak” penulis menggunakan metode penulisan yaitu studi pustaka. Penulis dalam hal ini mencari buku-buku penunjang yang berkaitan dengan baptisan anak yang ditolak oleh beberapa golongan gereja yang tidak mengakui baptisan anak. Selain berkaitan dengan buku-buku baptisan, berkaitan juga dengan artikel-artikel yang menjelaskan tentang Baptisan anak dan pengajaran-pengajaran baptisan yang bertentangan dengan golongan tersebut. Penggalian eksegesis dilakukan melalui buku-buku tafsiran Alkitab mengenai teks 1Korintus 10: 1-5. Dengan menggunakan metode ini penulis dapat memaparkan pemahaman tentang prinsip baptisan anak berdasarkan hasil studi eksegetis 1Korintus 10: 1-5 dan kontribusinya dalam memahami prinsip baptisan anak.

\section{HASIL}

Penggalian teks 1Korintus 10: 1-5, dapat menjawab dan mempertegas kembali prinsip Alkitabiah dari kata baptisan Anak. Berdasarkan pemahaman baptisan berdasarkan 1Korintus 10: 1-5 dapat memberikan kontribusi dalam memberikan pengajaran tentang pemahaman bapatisan anak untuk gereja dan orang percaya. Penulisan ini untuk menunjukkan bahwa tradisi baptisan dalam teologi Reformed adalah prinsip doktrin yang dapat dipertanggungjawabkan kebenarannya. Melalui penulisan artikel ini dapat menolong memberikan pembelaan ajaran baptisan anak secara Alkitabiah, dengan kajian dan kaidah keilmuan yang dapat dipertanggungjawabkan. 


\section{PEMBAHASAN}

Dalam pembahasan ini akan menuliskan tentang signifikansi baptisan anak, studi eksegetis 1Korintus 10: 1-5, problematika baptisan anak dan kontribusi dalam memahami prinsip baptisan anak.

\section{Signifikansi Baptisan Anak}

Ada banyak tulisan yang membahas tentang baptisan anak, namun belum banyak yang mengekspos dan menggunakan 1Korintus 10: 1-5 menjadi dasar referensi, hal tersebut dapat terlihat dari buku katekismus besar yang ditulis oleh Martin Luther. ${ }^{3}$ Katekismus Heildelberg juga menjelaskan tentang baptisan anak dalam pengajaran minggu ke-27 pertanyaan nomor $74 .^{4}$ Katekismus Besar Westminster dalam pertanyaan jawab nomor 166 bagian b. ${ }^{5}$ Katekismus Kecil Westminster dalam bagian pertanyaan nomor 95 bagian b. ${ }^{6}$ Selain itu, di dalam buku pengakuan iman Gereja Perancis pasal XXVIII bagian Sakramen-Sakramen nomor 35 bagian c, ${ }^{7}$ dan di dalam buku Pengakuan iman Westminster. ${ }^{8}$

Berdasarkan pemahaman ini, pengetahuan mengenai baptisan anak berdasarkan 1Korintus 10: 1-5 dapat menjadi kontribusi bagi pemahaman prinsip baptisan anak. hal ini didasarkan adanya gejolak dan pertentangan yang terus

${ }^{3}$ Anwar Tjen, Katekismus Besar Martin Luther (Jakarta: BPK Gunung Mulia, 2011), 195-200.

${ }^{4}$ Van den End, Enam Belas Dokumen Dasar Calvinisme (Jakarta: BPK Gunung Mulia, 2004), 218.

${ }^{5}$ Akan tetapi anak-anak dari orang tua yang mengaku percaya dan taat kepada Kristus, apakah yang keduanya atau seorang saja, dari sudut pandangan itu termasuk perjanjian, dan harus di baptis.

b. Kej. 17: 7, 9 bersama Gal. 3: 9, 14, dan Kol. 2: 11-12, dan Kis. 2: 38-39, dan Rm. 4: 11-12; 1 Kor. 7: 14; Mat. 28: 19; Luk. 18: 15-16; Rm. 11: 16 (Lih.: End, 301.)

${ }^{6}$ Akan tetapi, anak-anak para anggota Gereja yang kelihatan harus dibaptis. b. Kis. 2: 38-39; Kej. 17: 10 bersama Kol. 2: 11-12; 1 Kor. 7: 14 (Lih.: End, 328.)

7 Baptisan memang merupakan sakramen iman dan pertobatan; namun, karena Allah menerima anak-anak kecil ke dalam Gereja-Nya bersama bapak-bapak mereka, kita berkata bahwa berdasarkan kuasa Yesus Kristus anak-anak kecil orang percaya harus dibaptis.

c. Mat. 19: 14; 1 Kor. 7: 14 (Lih.: End, 15.)

8 Yang harus dibaptis bukan hanya mereka yang nyata-nyata mengikrarkan iman dan kepatuhannya kepada Kristus, ${ }^{a}$ melainkan juga kanak-kanak, bila satu orang tua atau keduanya adalah orang percaya. ${ }^{b}$ a. Mrk. 16: 15-16; Kis. 8: 37-38; b. Kej. 17: 7, 9-10 bersama Gal. 3: 9, 14 dan Kol. 2: 11-12 serta Kis. 2: 38-39 dan Rm. 4: 11-12; 1 Kor. 7: 14; Mat. 28: 19; Mrk. 10: 13-16; Luk. 18: 15 (Lih.: End, 134.) 
dihadapi oleh orang percaya dalam mempertahankan iman yang berhubungan dengan baptisan anak. Keraguan yang dialami orang Kristen dapat menimbulkan kekeliruan yang berkesinambungan. Dengan pemahaman yang tepat dapat mengatasi pemahaman yang keliru terhadap baptisan.

Baptisan merupakan kewajiban yang telah dilaksanakan oleh orang percaya sejak zaman PL hingga zaman Perjanjian Baru (PB). Dalam PL baptisan dilambangkan dengan sunat (Band. Kejadian 17: 9-14). Dengan kata lain, baptisan yang menggantikan sunat (Band. Kolose 2: 11-12). Hal ini berdampak dengan pemahaman jemaat mengenai makna sakramen baptisan kudus yang telah dilaksanakan oleh orang percaya sebagai tanda dan materai umat Allah. Namun, pemahaman terhadap baptisan menimbulkan banyak perbedaan pendapat. Salah satunya mengenai baptisan anak yang banyak diragukan keabsahannya oleh beberapa golongan orang percaya. Hal ini mengakibatkan adanya perdebatan antar golongan orang percaya.

Golongan aliran Luther mengakui adanya baptisan anak yang dilaksanakan dalam gereja. Menurut Luther dalam mempertahankan pemahamannya tentang baptisan anak untuk mengatasi keraguan yang dialami oleh orang-orang protestan di Swiss bahwa:

Tidak perlu orang mempunyai iman yang matang untuk menerima baptisan, sebab bukan imanlah yang menjadikan baptisan efektif, melainkan janji Allah. Orang tua yang memberi bayi mereka untuk dibaptis boleh percaya bahwa Allah akan memberi anak mereka iman yang diperlukan untuk menikmati rahmat baptisan, bahkan mereka boleh percaya bahwa benih iman sudah ditanam Allah dalam anak mereka. Dengan singkat dapat dikatakan bahwa Luther menerima baptisan bayi atas dasar praduga bahwa anak kecil itu sudah mempunyai iman. ${ }^{9}$

${ }^{9}$ Christian De Jong, Apa Itu Calvinis? (Jakarta: BPK Gunung Mulia, 2001), 191. 
Dengan demikian, pemahaman Luther mengakui keabsahan baptisan anak. selain pemahaman dari Luther, menurut De Jonge mengutip Calvin menyatakan menerima keabsahan baptisan anak. ${ }^{10}$

Berdasarkan pendapat di atas beberapa Bapak Gereja menerima baptisan anak dengan alasan baptisan anak merupakan janji Allah bagi umat-Nya. Namun, baptisan anak tidak secara menyeluruh diterima oleh setiap denominasi gereja Kristen di dunia. M. Ferry H.Kakiay menuliskan:

Perlu dicatat bahwa syarat baptisan adalah percaya bahwa Tuhan Yesus Kristus sebagai Juruselamat dan bertobat serta mentaati perintah-perintahNya. Seorang bayi belum tentu mengerti tentang pertobatan dan iman yang sejati. Karena itu Gereja Bethel Indonesia (GBI) tidak melakukan baptisan kepada bayi, namun yang dilakukan adalah penyerahan anak (1 Samuel 1: 27-28; Lukas 2: 22). Tuhan Yesus Kristus tidak melakukan baptisan kepada anak-anak kecil, melainkan memeluk anak-anak itu-meletakan tangan di atasnya dan memberkati mereka (Markus 10: 13-16). ${ }^{11}$

Sehingga, pandangan golongan tersebut baptisan anak tidak diakui keabsahannya. Karena berlandaskan pada pemahaman makna baptisan yang berarti pertobatan dan iman yang sejati. Sedangkan anak-anak belum mengerti

10 Dari kesejajaran sunat dan baptisan, maka disimpulkan bahwa sama seperti sunat pada zaman Perjanjian Lama, pada zaman Perjanjian Baru, yang tetap berlaku sekarang, baptisan boleh, bahkan harus dilayankan kepada bayi. Lebih lanjut diberi alasan bahwa kalau anak-anak Israel disunat karena tercangkup dalam Perjanjian Allah dengan Israel, maka lebih-lebih lagi anak-anak orang-orang percaya dibaptis (dan hanya mereka, lihat dibawah) karena tercangkup dalam PBdalam Kristus dengan orang tua mereka. Disini dipakai cerita mengenai Yesus dan anak-anak (Mrk. 10: 13-16 dan parelel-paralel) sebagai bukti bahwa kasih karunia-Nya meluas sampai mereka juga. Semua bukti Alkitabiah ini menurut Calvin cukup mengimbangi kenyataan bahwa bukti langsung mengenai baptisan anak-anak dalam PBtidak ada. (perhatikan kejujuran ilmiah Calvin sebagai ahli tafsir). Dalam gagasan Calvin bahwa keabsahan baptisan anak-anak terletak dalam perjanjian anugerah antara Allah dan gereja, kita melihat alasan pokok mengapa ia hendak mempertahankan tradisi gereja untuk mambaptis bayi yang baru lahir. Hal itu tampak dari uraian pendek yang diberikan mengenai manfaat baptisan anak-anak. melalui baptisan anak-anak, iman para orang tua diperkuat, karena dinyatakan dengan tanda yang kelihatan ahwa kesetiaan Allahberlaku juga untuk anakanak mereka, bahkan turun-temurun. Akan tetapi juga untuk anak-anak sendiri baptisan sangat berguna. Penting bagi mereka untuk sedini mungkin dimasukan kedalam persekutuan gereja, karena dengan demikian mereka dapat dibina sejak awal. Lebih lanjut, pada saat menjadi dewasa, kesadaran bahwa mereka telah diterima oleh Allah sebagai anak-Nya, sebelum mereka dapat mengakui Allah sebagai Bapa, menjadi dorongan untuk berbakti kepada-Nya dengan sungguh-sungguh. Oleh karena itu menolak baptisan anakanak sama saja dengan menyepelekan perjanjian yang ada antara Allah dan anak-anak serta anugerah yang ditawarkan kepada manusia didalamnya, suatu sikap yang menurut Calvin dikyuk oleh Allah. (Lih.: Jong, 197-198.)

${ }^{11}$ M. Ferry H. Kakiay, Teologi GBI Suatu Refleksi Terhadap Wacana Teologi Yang Berkembang Di GBI (Jakarta: Kapernaum, 2003), 68. 
tentang pertobatan dan iman. Dengan demikian, pemahaman dari pendapat kelompok di atas adalah problematika bagi pemahaman baptisan anak.

Dalam hal ini beberapa teolog menentang pandangan kelompok tersebut tentang baptisan anak, Louis Berkhof menuliskan:

Pandangan teolog yang setujuh mengenai baptisan anak termuat di dalam buku Teologi Sistematika tentang Doktrin Gereja mengenai baptisan sebelum zaman Reformasi "Bahkan Agustinus juga tampaknya menganggap bahwa baptisan adalah ex opere operato yang efektif dalam diri anak-anak. Ia menganggap baptisan sebagai sesuatu yang sangat perlu dan ia mengatakan bahwa anak-anak yang tidak dibaptis akan terhilang". ${ }^{2}$

Dengan demikian, signifikasi pemahaman tentang baptisan anak sangat berpengaruh dalam menghadapi pemahaman yang berbeda. Pemahaman ini dapat berdampak bagi pertumbuhan iman jemaat di masa postmodern. Sehingga, perlu adanya pemahaman yang tepat berdasarkan Firman Tuhan.

\section{Studi Eksegetis 1Korintus 10: 1-5}

Surat 1Korintus merupakan kesatuan dari surat 2Korintus. Surat ini termasuk ke dalam 13 surat yang telah ditulis oleh rasul Paulus. Surat ini ditulis menjelang akhir persinggahannya di Efesus, karena ia telah menyusun rencana untuk meninggalkan Asia dan mengadakan kunjungan yang lebih lama ke Makedonia dan Akhaya (1Korintus 16: 5-7). Mungkin ia ditulis selama musim dingin atau musim gugur, karena ia berbicara mengenai tinggal di Efesus hingga hari Pentakosta karena ia melihat banyak pekerjaan yang berpengharapan besar (16: 8). Ia sedang sibuk mengumpulkan dana sumbangan bagi orang-orang miskin di Yerusalem, yang dibawanya serta dalam perjalanannya yang terakhir ke kota itu (Kis. 24: 17), dimana ia berfikir untuk kembali ke Palestina lagi dalam waktu

12 Louis Berkhof, Teologi Sistematika (Surabaya: Momentum, 2005), 141. 
dekat. Mungkin ia ditulis dalam musim dingin tahun $55 \mathrm{M}$, pada puncak kariernya di Efesus. ${ }^{13}$

Surat 1Korintus ini ditulis oleh Rasul Paulus bagi jemaat di Korintus. Korintus merupakan sebuah kota mediterania yang menjadi pusat budaya dan kepercayaan bagi orang Yunani. ${ }^{14}$ Selain itu, berbeda dengan Athena, Korintus juga merupakan tempat perdagangan internasional dan wisata. "Unlike Athens, Corinth was an internasional crossroads of Commerce and travel". ${ }^{15}$ Sehingga, Korintus merupakan kota yang strategis dan penuh beragam budaya kepercayaan. Dengan demikian, kedatangan rasul Paulus membawa dampak yang besar bagi orang-orang Korintus sebab mereka bukan berasal dari orang Yahudi, melainkan orang non Yahudi.

Dalam hal ini, Paulus memiliki beberapa alasan yang termuat di dalam surat 1 Korintus yang memiliki tujuan untuk menyelesaikan masalah yang terjadi di jemaat Korintus dan memberi bimbingan yang tepat atas pertanyaan-pertanyaan dari jemaat Korintus kepada Paulus. Ada beberapa pendapat mengenai tujuan penulisan surat 1 Korintus, antara lain:

Menurut Tenney dalam bukunya Survei Perjanjian Baru bahwa surat ini ditulis untuk menjawab persoalan-persoalan di dalam Gereja Jemaat di Korintus. Topik pembicaraannya berkisar dari perpecahan dalam jemaat, hingga keuangan dan dari tata krama gereja hingga kebangkitan. ${ }^{16}$ Permasalahan yang terjadi mulai dari 1Korintus 1: 10-17 tentang perpecahan dalam jemaat. Selain itu, menurut

${ }^{13}$ Merrill C. Tenney, Survey Perjanjian Baru (Malang: Gandum Mas, 1995), 367.

14 Corinth was one of the major urban centers of the ancient mediteranean and one of the most culturally diverse cities in the empire. (Lih.: Craig S. Keener, The IVP Bible Background Commentary New Testament (USA: IVP Academic, t.t.), 459.)

15 Craig A. Evans dan Stanley E. Porter, Dictionary Of New Testament Back Ground (USA: IVP Academic, 2000), 228.

16 Tenney, Survey Perjanjian Baru, $\underline{367}$. 
buku penuntun hidup berkelimpahan, Paulus memiliki dua alasan dalam surat 1Korintus ini, yaitu: pertama, untuk membetulkan masalah yang serius dalam jemaat di Korintus yang sudah diberitahukan kepadanya. Hal-hal ini mengenai pelanggaran yang dianggap remeh oleh orang Korintus, tetapi dianggap oleh Paulus sebagai dosa serius. Kedua, untuk memberi bimbingan dan instruksi atas berbagai pertanyaan yang telah ditulis oleh orang Korintus. Hal-hal ini meliputi soal doktrin dan juga perilaku dan kemurnian sebagai perorangan dan sebagai jemaat.

Surat 1Korintus 10: 1-5 menjelaskan tentang sejarah keluarnya bangsa Israel dari tanah Mesir dan kisah dalam perjalanan menuju tanah Kanaan. Banyak mujizat yang terjadi saat bangsa Israel keluar dari tanah mesir, salah satunya berjalan di bawah lindungan awan dan menyebrang laut Teberau yang terbelah menjadi dua. Kejadian ini secara turun temurun diberitakan di keturunan Israel. Dalam PL kisah keluarnya bangsa Israel dari tanah Mesir terdapat pada Kitab Keluaran. Secara khusus mengenai tuntunan TUHAN menggunakan tiang awan di siang hari (lih. Kel. 13: 21-22, 14: 19-20) dan kisah bangsa Israel menyeberang laut Teberau yang terbelah dua oleh tongkat Musa (lih. Kel. 14: 15-31).

Dalam hal ini Paulus menggunakan kisah keluarnya bangsa Israel dengan penyertaan tiang awan dan menyeberang laut Teberau kepada jemaat di Korintus sebagai suatu peringatan. Perjalanan bangsa Israel keluar dari tanah Mesir mencangkup golongan dewasa dan anak-anak serta ternak maupun barang-barang bawaan mereka. Sehingga, secara khusus dalam ayat 1-2 membahas tentang makna baptisan bagi bangsa Israel (yang disebut sebagai generasi hutan belantara) 
dalam awan dan laut. ${ }^{17}$ Dalam ayat ini Paulus menekankan bahwa bahwa perintah dalam peringatan akan baptisan sangat penting bagi jemaat di Korintus. Sebab pada zaman itu jemaat di Korintus mengalami permasalahan dan perilaku jemaat yang sudah bergeser dari imannya. Tentang hidup yang tidak setia kepada Tuhan karena ada penyembahan berhala dan moral yang menurun, sehingga Paulus mengingatkan jemaat di Korintus dengan kisah keluarnya bangsa Israel dari Mesir. Paulus memiliki alasan yang kuat bahwa mengulang kembali kisah nenek moyang akan membuat jemaat kembali berbalik kepada Tuhan sebagai peringatan bagi mereka bahwa pelanggaran akan berakibat hukuman dan perlu ada pembaharuan serta kembali kepada Firman Tuhan. Terutama mengenai baptisan yang membentuk nilai kerohanian jemaat yang sudah mulai lari dari Firman Tuhan. Ayat ini membahas tentang makna baptisan yang dilakukan bagi seluruh bangsa Israel yang keluar dari Mesir bukan menggunakan air tetapi dalam awan dan laut sehingga Paulus mereview kisah ini bagi jemaat di Korintus. ${ }^{18}$ Dalam ayat ini, menekankan bahwa bagi pengikut Musa harus dibaptis dalam awan dan laut, artinya bahwa tidak ada satu orangpun yang luput dari janji Allah yaitu tanda meterai sebagai umatnya yang dilambangkan dalam baptisan. Pemahaman ini juga di tegaskan oleh Keener mengenai 1Korintus 10: 1-2 dalam buku nya "The IVP Bible Background Commentary" bahwa:

Some later Jewish teacher also drew parallels between the Red Sea and Jewish proselyte baptism. Paul parallels the experience of salvation in the first exodus and salvation in Jesus to show that salvation does not render

$17 \mathrm{He}$ begains by claiming that the wilderness generation also received baptism; that is, the wildreness generation's deliverance compares to Christian deliverance symbolized in baptism. (Lih.: David E. Garland, I Corinthians Baker Exegetical Commentary On The New Testament (USA: Baker Academic, 2003), 449.)

18 Since the peoPL e were not covered with water but miraculously crossed the sea on dry ground (exod. 14: 22)-unless Paul somehow knew the legend that the peoPL e went into the sea up to their noses before it finally parted- calling this "baptism" may seem far-fetched. (Lih.: Garland, 449.) 
one invulnerable to falling (10: 6-12). (Jewish peoPL e were awaiting a new exodus, promised bye the prophets for the time of the Messiah). For the comparison, he emPL oys Christian language: baptism "into Moses" recalls baptism "into Christ" (12: 13). ${ }^{19}$

Dalam pemahaman ini menegaskan bahwa baptisan Musa mengingatkan baptisan dalam Kristus. Artinya bahwa baptisan pada zaman Musa menggambarkan baptisan saat kedatangan Kristus. Selain itu, menurut David E. Garland bahwa kata baptisan melalui Musa yang dalam bangsa bukan Yahudi sejajar dengan Paulus dari khas Kristen yaitu baptisan dalam Kristus. ${ }^{20}$ Baptisan itu berlaku bagi semua umat TUHAN sebagai orang dewasa atau anak-anak.

Dalam surat 1Korintus 10: 1-5 dalam ayat 1-2 yang membahas mengenai baptisan zaman Musa ketika bangsa Israel keluar dari tanah Mesir. Menurut nas Alkitab ini menjelaskan prinsip-prinsip baptisan anak, yaitu, pertama bahwa baptisan merupakan hak bagi setiap umat Tuhan dari sejak zaman PL ketika bangsa Israel menjadi umat Allah dalam wujud sunat. Namun, zaman PB disebut sebagai baptisan dalam lindungan awan dan dalam laut ketika bangsa Israel keluar dari Mesir menuju tanah Kanaan. Kedua, baptisan menjangkau semua golongan dewasa maupun anak-anak yang ikut bersama dalam perjalanan itu.

Berdasarkan hasil eksegesis 1Korintus 10: 1-5 mengenai perjalanan bangsa Israel keluar dari tanah Mesir yang di dalamnya terkandung makna baptisan dan kontribusinya dalam memahami prinsip baptisan anak yang menegaskan kembali bahwa baptisan bukan hanya berlaku zaman Perjanjian Baru, namun berawal dari zaman PL bagi bangsa Israel. Dalam perjanjian antara Allah

19 Keener, The IVP Bible Background Commentary New Testament, 479.

20 The phrase "baptism into Moses" (e,ivz tóv Mwu;sh/n evbaptisqhsan, eis ton Moÿsēen ebaptisthesan) has no Jewish parallels and appears to have been coined by Paul from the Christian Idiom "baptized into Christ" (Rom. 6: 3; Gal. 3: 27; cf. Matt 28: 19; Acts 8: 16; 19: 5; 1Cor. 1: 13; so Barret 1968: 221; Willis 1985b; Schrage 1995: 390; Wollff 1996: 215). (Lih.: Garland, I Corinthians Baker Exegetical Commentary On The New Testament, 450.) 
dengan umat-Nya melalui sakramen baptisan (sunat dalam Perjanjian Lama) di tentukan untuk semua golongan, yaitu orang dewasa maupun anak-anak. Dengan demikian, baptisan bukan berdasarkan usia, namun berdasarkan perintah TUHAN sebagai tanda materai umat-Nya.

\section{Problematika Baptisan Anak}

Kata 'baptis' berasal dalam bahasa Yunani $\beta \alpha \pi \tau i \zeta \omega$ kata ini berarti membasuh (dalam penyucian ritual orang Yahudi); membaptis. ${ }^{21}$ Selain memiliki arti membasuh dan penyucian, menurut Geoffrey W. Bromiley dalam bukunya Theological Dictionary Of The New Testament baptisan berarti masuk ke dalam air, masuk ke dalam bak air, mandi dan membersihkan.

The meaning of bapto and baptizo. Bapto, "to dip in or under," "to dye," "to immerse," "to sink," "to bathe," "wash." The NT uses bapto only in the literal sense, e.g., "to dip" (Lk. 16: 24), "to dye" (Rev. 19: 13), and baptizo only in a cultic sense, mostly "to baptize.",22

Apakah baptisan itu? Kata "membaptiskan" artinya membasahi, menyelamkan, membasuh (lih. Luk. 11: 38). Pembaptisan melambangkan pembersihan, yaitu pembersihan dari dosa. Ingatlah pembaptisan yang dilakukan oleh Yohanes Pembaptis (Mat. 3: 1-6; band. Kis. 19: 1-4). Ketika Yesus minta dibaptiskan, Ia mempersatukan diri dengan manusia yang berdosa (Mat. 3: 13-17; lih. bab 15). Kemudian Ia mewujudkan pengampunan, yakni dengan kematian dan kebangkitanNya. Demikianlah sakramen baptisan kudus mendapat maknanya yang sedalam-dalamnya: dengan Firman yang kelihatan” ini kita yakini tentang pengampunan yang dikerjakan oleh Kristus.

21 Hasan Sutanto, Perjanjian Baru Interlinear Yunani-Indonesia dan Konkoordansi (PBIK), vol. 2 (Jakarta: LAI, 2014), 133.

22 Geoffrey B. Bromiley, Theological Dictionary Of The New Testament (USA: Library Of Congress Cataloging in Publication Data, 1985), 92. 
Sebab itu Rasul Paulus berkata, bahwa kita dibaptiskan dalam kematian Kristus (Rom. 6: 3-11). Maksudnya: pembaptisan itu menandakan, bahwa diri kita, yang disebut "manusia lama" mati bersama Kristus, agar kita bangkit pula bersama Dia sebagai "manusia baru."

Dengan kata lain ketika kita dibaptiskan, Tuhan memberi jaminan yang senyata-nyatanya, bahwa kita termasuk kepada perjanjian baru, yang didirikan dibukit Golgota. Sebab itu kedua sakramen itu disebut "tanda dan materai dari perjanjian Allah.” Maksudnya: jaminan itu diberikan Tuhan dengan tanda yang kelihatan (sama seperti cap yang sehelai kertas materai), agar semakin teguh keyakinan kita akan keselamatan yang disediakanNya. Sebab itu anak-anak pun boleh dibaptiskan: bagi mereka itu pun perjanjian Allah dan janji-janji-Nya berlaku juga.

Baptisan itu harus disambut dan dijawab dengan percaya. Dan percaya itu dikerjakan oleh Roh Kudus dalam hati orang yang mau menerima-Nya. Maka pembaptisan yang sebenarnya dilakukan oleh Roh Kudus, yang membuat kita "dilahirkan kembali" (band. Titus 3: 5). Meskipun anak-anak belum mengerti seluruhnya, tetapi baptisan itu menjamin, bahwa Roh Kudus sungguh bersedia berbuat demikian. Justru baptisan anak-anak menegaskan kepada kita, bahwa janji-janji Allah mendahului jawaban kita (Band. 1Yoh. 4: 10). ${ }^{23}$

Dengan demikian, baptisan disambut dengan percaya oleh dorongan Roh Kudus setiap hati orang percaya yang menerimanya. Termasuk bagi anak-anak yang telah dipilih Allah sejak dalam kandungan sebagai umat-Nya dan baptisan anak dapat dilaksanakan oleh orang Kristen sebagai bagian dari sakramen

23 B.J Boland, Intisari Iman Kristen (Jakarta: BPK Gunung Mulia, 2011), 73. 
baptisan yang telah dijelaskan berdasarkan pengertian dan makna baptisan yang sebenarnya.

Namun, baptisan anak tidak mudah diterima oleh beberapa golongan Kristen berdasarkan pemahaman mereka yang berbeda mengenai baptisan. Salah satunya adalah golongan Anabaptis. Dengan beberapa alasan yang digunakan untuk menentang baptisan anak. menurut Anabaptis, baptisan anak yang mereka terima dari GKR bukanlah baptisan yang Alkitabiah, karena itu tidak sah. ${ }^{24}$ Menurut kaum Anabaptis, anak-anak belum bisa mengakui iman mereka dihadapan Tuhan. Sebab anak-anak belum bisa percaya kepada Tuhan dan belum mengerti apa itu iman. Anak-anak diidentikan dengan sebuah kertas kosong yang belum mengerti tentang iman Kristen. Seperti yang dikatakan oleh Horton:

From a covenantal perspective, it is impossible to separate the claim that the children of believers are holy (1Co 7: 14) from the sign and seal of the covenant. According to the traditional Anabaptist/Baptist view, the children are not regarded as holy until they personally repent and believe. ${ }^{25}$

Selain dari belum bisa mengakui iman, anak-anak juga dikatakan belum bisa sungguh-sungguh percaya kepada Tuhan sebab pemikiran mereka belum mengarah kepada hal-hal rohani. Hal ini sesuai dengan tingkat pemahaman anakanak yang masih polos dan belum mengenal Tuhan secara pribadi. Pemahaman ini dikatakan oleh kaum Baptis (kaum Mennonit), baptisan yang sah haruslah diberlakukan bagi orang yang sudah mampu memahami dan menyatakan imannya, berarti harus orang dewasa. ${ }^{26}$

Alasan terakhir yang sangat berpengaruh dalam penolakan baptisan anak yaitu bahwa anak-anak belum bisa mempertanggungjawabkan imannya kepada

24 Jan S. Aritonang, Garis Besar Sejarah Reformasi (Bandung: Jurnal Info Media, 2007), 64.

25 Michael Horton, Christian Faith (Zondervan, 2010), 795Michael Horton, Christian Faith (Michigan: Zondervan Publishing House, 2010), 795.

${ }^{26}$ Aritonang, Garis Besar Sejarah Reformasi, 71. 
Tuhan. Sebab, pemikiran mereka belum menuju iman Kristen atau disebut kehidupan rohani. Menurut kaum anabaptis. Baptisan bukan baptisan anak (yang mereka nilai sebagai kekejian utama yang dilakukan oleh Paus), melainkan bagi mereka yang secara sadar memilih menjadi kristen. ${ }^{27}$

Berdasarkan alasan-alasan yang dijelaskan oleh pemahaman golongan yang menolak pelaksanaan baptisan anak di gereja. Mereka melakukan sebuah upacara yaitu penyerahan anak dihadapan Tuhan, hal ini didasari oleh pemikiran bahwa setiap orang tua bertanggung jawab menyerahkan anak mereka di dalam pimpinan Tuhan.

\section{Kontribusi Dalam Memahami Prinsip Baptisan Anak}

Pemahaman yang keliru mengenai makna baptisan dan alasan-alasan menolak baptisan anak oleh beberapa teolog dan golongan Kristen bertentangan dengan makna baptisan yang sebenarnya berdasarkan Alkitab. Secara khusus surat 1Korintus 10: 1-5 yang mempertegas mengenai makna baptisan yang berpengaruh pada pelaksanaan baptisan anak bagi umat Allah. Selain itu, ada beberapa teks Alkitab lainnya yang mendukung pelaksanaan baptisan anak yang menjadi alasan bahwa baptisan anak sangat penting. Yaitu, Pemahaman tentang pentingnya baptisan anak dijelaskan dalam tiga bagian, yaitu:

\section{Baptisan sebagai tanda materai umat Allah}

Pemahaman tentang baptisan yang sesuai dengan Alkitab ialah dimaknai sebagai tanda materai umat Allah. Tanda materai merupakan sebuah simbol yang mengungkapkan bahwa benda tersebut dimiliki oleh tuan yang empunya materai tersebut. Sehingga, benda itu tidak bisa diambil oleh orang lain dari tangan

27 Aritonang, 65. 
tuannya. Sebab, tanda materai sudah mensahkan kepemilikan. Seperti yang dikatakan oleh Calvin bahwa baptisan diajukan Tuhan kepada kita sebagai tanda dan bukti tentang pembersihan kita; atau, supaya maksud saya diterangkan dengan lebih jelas, sebagai suatu surat bermaterai yang menegaskan kepada kita bahwa segala dosa kita telah dihapuskan, dicoret dan ditiadakan sedemikian rupa hingga tak bakal muncul dihadapan-Nya, dan tidak akan diingat atau diperhitungkan kepada kita. Sebab Ia mengkehendaki supaya semua orang yang percaya dibaptis untuk pengampunan dosa mereka. ${ }^{28}$

\section{Anak-anak tergolong umat perjanjian}

Selain daripada itu, anak-anak juga tergolong sebagai umat perjanjian Allah sehingga anak-anak berhak menerima baptisan kudus sebagai tanda materai umat perjanjian berdasarkan Alkitab. Perkataan ini dikatakan oleh Tuhan Yesus sendiri dalam Matius 19: 14, bahwa "Biarkanlah anak-anak itu, janganlah menghalang-halangi mereka datang kepada-Ku; sebab orang-orang yang seperti itulah yang empunya Kerajaan Sorga.” Ayat Alkitab ini menjelaskan bahwa betapa anak-anak berharga dimata Tuhan dan merupakan bagian dari Kerajaan Sorga.

Selain itu dalam PL juga dijelaskan bahwa anak-anak termasuk umat perjanjian Allah yang harus berpegang pada perjanjian yang Allah tetapkan. Terdapat dalam Mazmur 132: 12, yang berbunyi: jika anak-anakmu berpegang pada perjanjian-Ku, dan pada peraturan-peraturan-Ku yang Kuajarkan kepada mereka, maka anak-anak mereka selama-lamanya akan duduk di atas takhtamu. Dengan jelas ayat ini menjelaskan bahwa anak-anak Israel juga termasuk umat

28 Yohanes Calvin, Institutio (Jakarta: BPK Gunung Mulia, 1980), 229. 
perjanjian, bukan hanya orang dewasa yang termasuk umat perjanjian sebab, anak-anak merupakan generasi penerus umat perjanjian Allah.

Dalam perspektif Reform anak-anak termasuk ke dalam umat perjanjian. ${ }^{29}$ Dengan demikian, dalam pandangan Reform anak-anak juga berhak menerima baptisan anak sesuai dengan perjanjian Allah dengan Abraham dan keturunannya turun temurun.

\section{Anak-anak dapat percaya kepada Tuhan}

Meskipun banyak teolog dan golongan yang menolak pelaksanaan baptisan anak berdasarkan pemahaman mereka yang belum memahami iman Kristen, anak-anak sebenarnya dapat percaya kepada Tuhan. Hal ini berdasarkan pemahaman Alkitab mengenai anak-anak yang lahir dari keluarga orang percaya, salah satunya adalah Timotius yang dipakai Tuhan sejak mudanya. Timotius berasal dari keluarga yang sungguh-sungguh percaya kepada Tuhan yang setiap hari mendengar cerita Firman Tuhan melalui neneknya Lois dan ibunya Eunike (lih. 2 Timotius 1: 5).

Selain itu, dalam buku Institutio pembelaan Calvin: Baptisan mempunyai arti yang sama dengan sunat dalam Perjanjian Lama. ${ }^{30}$ Seperti telah dibahas sebelumnya, Luther mengatakan bahwa baptisan adalah kehendak Allah, bukan kehendak manusia. Oleh sebab itu, baik anak-anak ataupun orang dewasa, jika baptisan itu atas nama Allah Bapa, Anak dan Roh Kudus, maka baptisan itu adalah sah adanya. 


\section{KESIMPULAN}

Studi eksegetis 1Korintus 10: 1-5 memaparkan pandangan mengenai baptisan yang ditekankan oleh rasul Paulus bagi jemaat di Korintus yang memberikan kontribusi bagi pemahaman prinsip baptisan anak. Di dalam teks Alkitab ini menjelaskan tentang makna yang sesungguhnya mengenai baptisan yang merupakan materai atau tanda sebagai umat perjanjian Allah. Namun,banyak pemahaman makna baptisan yang berbeda-beda sehingga menjadi problematika bagi banyak teolog dan aliran Kristen di dunia. Ternyata beberapa aliran menganggap baptisan sebagai penyucian/pembersihan terhadap dosa. Sehingga baptisan difokuskan hanya untuk orang dewasa yang sudah bisa mengakui iman dan mempertanggung jawabkan imannya kepada Tuhan. Ini merupakan pemahaman yang keliru, sebab dalam nas ini menegaskan bahwa baptisan berlaku bagi semua orang percaya, yaitu orang dewasa dan anak-anak. Sebab anak-anak juga termasuk umat pilihan Allah yang ikut keluar bersama orang tua mereka dari Mesir menuju tanah Kanaan. Anak-anak ikut menyeberang laut Teberau dan dalam perlindungan awan dan api.

Dengan demikian, prinsip pemahaman baptisan anak sangat signifikansi bagi jemaat, bermanfaat untuk menguatkan iman bahwa sejak kecil anak-anak orang percaya berhak menerima baptisan berdasarkan perjanjian dengan Allah. Dengan dasar ini pandangan terhadap sakramen baptisan tidak hanya sebagai penghapusan dosa dan pembaharuan hidup, tetapi yang terpenting ialah sebagai materai umat perjanjian Allah.

Oleh karena itu melalui studi ini menyimpulkan bahwa baptisan anak adalah sakramen baptisan yang Alkitabiah. Hal tersebut didasarkan pada prinsip yang digambarkan melalui Allah yang bertindak menjadikan umat Israel sebagai 
umat perjanjian melalui peristiwa penyeberangan Laut Teberau yang memisahkan umat Israel dari daerah perbudakan di Mesir. Pemisahan tersebut dilakukan dengan terbelahnya laut teberau sehingga umat Israel setelah melewatinya tidak dapat kembali lagi namun terus melanjutkan ke daerah tanah Perjanjian. Demikian juga baptisan anak sebagai pernyataan bahwa anak yang dibaptis memasuki perjanjian sebagai umat Allah.

\section{DAFTAR PUSTAKA}

Aritonang, Jan S. Garis Besar Sejarah Reformasi. Bandung: Jurnal Info Media, 2007.

Berkhof, Louis. Teologi Sistematika. Surabaya: Momentum, 2005.

Boland, B.J. Intisari Iman Kristen. Jakarta: BPK Gunung Mulia, 2011.

Bromiley, Geoffrey B. Theological Dictionary of The New Testament. USA: Library Of Congress Cataloging in Publication Data, 1985.

Calvin, Yohanes. Institutio. Jakarta: BPK Gunung Mulia, 1980.

End, Van den. Enam Belas Dokumen Dasar Calvinisme. Jakarta: BPK Gunung Mulia, 2004.

Evans, Craig A., dan Stanley E. Porter. Dictionary Of New Testament Back Ground. USA: IVP Academic, 2000.

Garland, David E. I Corinthians Baker Exegetical Commentary On The New Testament. USA: Baker Academic, 2003.

Horton, Michael. Christian Faith. Michigan: Zondervan Publishing House, 2010.

Jong, Christian De. Apa Itu Calvinis? Jakarta: BPK Gunung Mulia, 2001.

Kakiay, M. Ferry H. Teologi GBI Suatu Refleksi Terhadap Wacana Teologi Yang Berkembang Di GBI. Jakarta: Kapernaum, 2003.

Keener, Craig S. The IVP Bible Background Commentary New Testament. USA: IVP Academic, t.t.

N, N. “Anabaptism.” En.wikipedia.org. Wikipedia. Diakses 25 September 2019. https: //en.wikipedia.org/wiki/Anabaptism. 
Soru, Esra Alfred. "Baptisan Anak Tanggung Jawab Orang Tua dan Gereja." Anchoroflife.blogspot.com. Church of Life (blog), Juli 2011. https: //anchoroflife.blogspot.com/2011/07/baptisan-anak-tanggung-jawaborang-tua.html.

Sutanto, Hasan. Perjanjian Baru Interlinear Yunani-Indonesia dan Konkoordansi (PBIK). Vol. 2. Jakarta: LAI, 2014.

Tenney, Merrill C. Survey Perjanjian Baru. Malang: Gandum Mas, 1995.

Tjen, Anwar. Katekismus Besar Martin Luther. Jakarta: BPK Gunung Mulia, 2011. 